\title{
Does Financial Development Necessarily Lead to Economic Growth? Evidence from China's Cities, 2007-2014
}

\author{
Shiyong Zhao \\ School of Business, Macau University of Science and Technology, Macau, China \\ Corresponding author: syzhao@must.edu.mo.
}

\begin{abstract}
Using data from 286 Chinese cities over the period 2007-2014, this paper investigates the impact of financial development on economic growth. Our results from traditional cross-sectional regressions, first-differenced GMM and system GMM regressions all show that financial development does not have any significant positive effects on economic growth, while some indicators of financial development show significant negative effects on growth. Our results are consistent with many existing studies that a state-ruled banking sector, such as that of China, hinders economic growth because of the distoring nature of the government. To examine the sensitivity of our results, different sets of control variables sets are experimented with. Our results are shown to be robust. Our finding shows that to let the financial sector play a more efficient and effective role in promoting real economic growth, China has to further reform its financial system.
\end{abstract}

\section{Introduction}

Joseph Schumpeter argued in his seminal work The Theory of Economic Development (1911) [1] that the services provided by financial intermediaries are essential for technological innovation and economic development. They mobilize savings, evaluate projects, manage risk, monitor mangers, and facilitate transactions. Earlier empirical works by Goldsmith (1969) [2] and McKinnon (1973) [3] illustrate the close ties between financial and economic development for a few countries. Numerous influential economists, however, believe that finance is a relatively unimportant factor in economic development. Notably, Robinson (1952) [4] argues that financial development simply follows economic development. Lucas (1988) [5] terms the relationship between financial and economic development 'over-stressed.' In this paper we study whether higher levels of financial development are positively associated with economic growth using data on 286 Chinese cities from 2007 through 2014.

To examine whether Schumpeter (or Lucas) was right, we must define 'financial development' empirically. We construct four indicators of financial development that are designed to measure the services provided by financial intermediaries. First, we compute the traditional measure of financial depth, which equals the overall size of the formal financial intermediary system, i.e. the ratio of loans to GDP. Second, we measure the ability of financial intermediaries to mobilize capital, i.e., the ratio of deposits to GDP. Third, the ratio of households savings to GDP to measure the ability of financial intermediaries to attract household savings. Fourth, share of fixed asset investment financed by bank loans relative to state budgetary appropriation. It is believed that bank loans have more role than government appropriation in disciplinary the recipients. Although each financial indicator has shortcomings (sometimes due to data limitations), using this array of indicators provides a richer picture of financial development than if we used only a single measure.

China has been experiencing rapid economic growth and remarkable expansion of financial sector since 1978, when China started its economic transformation. China's real GDP has been growing at an annual average rate of 9.65 percent over 1978-2015 (NBS, 2016) [6]. Over the same period, the total loans outstanding in its financial institutions divided by GDP has increased from 51 percent to 147 percent (NBS, 2010, 2016)[6, 7]. As the largest emerging market and the second largest economy with rapid growth and dramatic transformation, China presents us with an intriguing case for study to test Schumpeter's view posed in 1911. Does finance play an important role in China's recent growth? This paper investigates this question by using a rich and most updated set of city-level data.

Many cross-country studies have shown that finance has an important impact on growth (to be reviewed in next section). China has been viewed as a counterexample to the common insight of the finance-growth literature, because on the one hand China has achieved fast economic growth for more than three decades, and on the other, China's financial sector has been controlled by the state very rigidly. For example, private investors are still not allowed to open 
a bank in China even today. Boyreau-Debray (2003) [8] finds that financial intermediation has a negative impact on local economic growth in China over 1990-1999 because the banking sector was mainly supporting the loss-making state-owned enterprises in the 1990s. Using provincial level data over 1986-2002, Hasan et al. (2009) [9] also finds that the financial sector has a negative impact on China's economic growth. Chen (2006) [10], however, finds that China's financial development has a positive effect on economic growth by using provincial-level data over 1985-1999. Cheng and Degryse (2007) [11] show that the development of banking services contributes positively to economic growth over 1995-2003.

Our finding in this paper suggests that financial development does not show a positive effect on economic growth over 2008-2013. This result is consist with some existing literature conclusions, which states that state-controlled banking sector impedes economic growth because banks tend to lend money mostly to inefficient large SOEs due to various reasons (to be explained later), although millions of small and medium-sized private firms have an urgent need for money. While deposits did climb as a share of GDP, there was little expansion of credit to the private sector, as many state banks remained in existence, and their habits of directing credit died hard (World Bank, 2005) [12]. Our finding contrasts sharply with the significant, robust relationship between the level of financial development and both the current and future rate of economic growth (e.g., King and Levein, 1993) [13].

\section{Literature review}

It is undoubted that financial market is essential to a country's economic growth and prosperity. Financial intermediaries are indispensable for the smooth functioning of financial markets. It may be in this sense that Miller (1988) [14] said, 'that financial markets contribute to economic growth is a proposition almost too obvious for serious discussion.' Other influential economists, however, believe that finance is a relatively unimportant factor in economic development. Lucas (1988) [5], for example, as mentioned above, said 'the importance of financial matters is very badly over-stressed in popular and even much professional discussion.' Apparently, there is no consensus among economists on the role of finance in promotion growth at least theoretically. It seems that this dispute should be solved empirically.

Early cross-country studies suggest a positive correlation between financial development and economic growth. King and Levine (1993) [13] present cross-country evidence consistent with the view that the financial system can promote economic growth, using data on 80 countries over 1960-1989 period. Compared with earlier work by Goldsmith (1969) [2] who arrives at the same conclusion, King and Levine (1993) [13] add more control variables affecting growth to the regression model, such as trade, education and political stability. Levine and Zervos (1998) [15] show that stock market liquidity and banking development can predict economic growth. We should remind ourselves that correlation does not prove causation. It is possible that a more developed financial sector is correlated with various other growth-enhancing factors, and it is other factors that promote growth. Technically, it is not easy to disentangle the effect of financial development from other factors. As Robinson (1952) [4] contends, financial development simply follows economic growth.

Using a country's legal origin as a valid instrumental variable, Levine (1999) [16] finds that financial development has a significant positive effect on economic growth. Levine et al. (2000) [17] confirms this conclusion by using the generalized moments of method (GMM) for dynamic panel data on a panel of 71 countries over 1960-1995. From the perspective of econometric techniques, dynamic panel models allow the use of instrumental variables for all the explanatory variables so that more precise estimates could be obtained than cross-sectional data. This is why more recent studies on the relationship between finance and growth use dynamic panel models. Rioja and Valey (2004) [18] explore the impact of financial development on sources of growth in different groups of countries with a panel dataset covering 74 countries. Beck et al. (2000) [19] uses GMM estimators for dynamic panel data and find that financial development has a significant and positive effect on total factor productivity (TFP) growth. Moreover, Rousseau and Wachtel (2002) [20] and Beck and Levine (2004) [21] find that some exogenous components of bank and stock market development have a large impact on economic growth. This result is also echoed by studies with time-series data, such as Xu (2000) [22], Christopoulos and Tsionas (2004) [23], and Bekaert et al. (2005) [24].

Apart from cross-country studies, there are also many researchers who focus on specific countries. This is advantageous because country-specific factors could be avoided in regression analysis. Jayaratne and Strahan (1996) [25] provide evidence that financial markets can directly affect economic growth by studying the relaxation of bank branch restrictions in the United States. They argue that the observed changes in growth are the result of changes in the banking system, and improvements in the quality of bank lending appear to be responsible for faster growth. Dehejia and Lleras-Muney (2003) [26] examine the effect of state-level banking regulation on financial development and economic growth in the U.S. from 1900 to 1940. In particular, they document that not all forms of financial development have a positive effect on economic growth, for example, indiscriminate lending can negatively impact economic growth. Japan's Meiji Restoration started from 1868, which successfully transformed Japan into an industrial power. Rousseau (1999) [27] studies this period from 1880 to 1913 and offers evidence that financial factors played a key role in leading to Japan's rise. Examining Italy's experience, Guiso et al. (2004) [28] suggest that local financial development is an important determinant of the economic success of an area even in an environment where there are no frictions to capital movements. 
Besides the above studies based on country-level data, there are also a lot of studies using more micro-level data, such as industry- or firm-level data. Rajan and Zingales (1988) [29] find that financial development facilitates economic growth, and the rationale is that financial development reduces the costs of external finance to firms. They find that industrial sectors that are relatively more in need of external finance develop disproportionately faster in countries with more-developed financial markets. Kumar et al. (1999) [30] show that size of firms in industries dependent on external finance is larger in countries with better financial markets, which means that the growing of firms relies on the support of financial markets. Wurgler (2000) [31] shows that financial markets 'appear to improve the allocation of capital,' thus conducive to economic growth. Cetorelli and Gambera (2001) [32] investigate the role played by the market structure of the banking sector on the dynamics of capital accumulation. This paper provides evidence that bank concentration promotes the growth of those industrial sectors that are more in need of external finance by facilitating credit access to younger firms. Claessens and Laeven (2003) [33] find evidence consistent with better property rights leading to higher growth through improved asset allocation. Quantitatively, the growth effect is as large as that of improved access to financing due to greater financial development. Using a unique firm-level survey database covering 54 countries, Beck et al. (2008) [34] investigate the effect of financial, legal, and corruption problems on firms' growth rates. They show that financial and institutional development weakens the constraining effects of financial, legal and corruption obstacles.

It seems that an overwhelming weight of the evidence from this body of research is that Schumpeter was right, i.e., financial development is good for economic growth, though, a consensus has not yet to emerge. Guariglia and Poncet (2008) [35] use data for 30 Chinese provinces over the period 1989-2003 and find that traditionally used indicators of financial development is negatively associated with growth its sources. According to them, this is because of financial distortions in China, which represent an impediment to growth. Hasan et al. (2009) [9] also argue that bank loans that are predominantly non-performing loans to SOEs are hardly likely to be growth inducing. From the literature, we conjecture that financial development is conducive to growth only when the financial system is efficient and the financial market is not heavily distorted.

\section{Variables and data}

We will use city-level data to examine the relationship between financial development and economic growth in recent China. Before that we must construct a number of indicators to measure financial development. And we also list some control variables and put them into different conditioning sets.

\subsection{Variables}

The dependent variable in our regression model is growth, which is measured by the annual growth rate of real GDP. The independent variables consist of variables indicating financial development and a conditioning information set controlling for other factors affecting economic growth.

We construct four indicators to measure financial development.

Loans, which is the ratio of total loans of national banking system to GDP. This ratio measures financial deepening.

Deposits, which is the ratio of total deposits of national banking system to GDP. This ratio measures the overall size of financial intermediaries and their capacity to mobilize capital.

Savings, which is the ratio of total household savings deposited in the financial institutions to GDP. This ratio serves as a proxy for the degree of China's financial development in mobilizing household savings.

Loan to appropriation, which is the share of fixed asset investment financed by domestic loans relative to the share financed by state fiscal appropriation. Fixed asset investment, which forms the capital, may be financed by difference sources, such as domestic loans, government appropriation, foreign investment, and self-raised funds. Among these various sources, loans are considered more efficient than state appropriation in terms of capital allocation. Following the literature (i.e., Liu and Li, 2001 [36]; Chen, 2006 [10]; Zhang et al., 2012 [37]), we use this ratio to measure the substitution of more market- and profit-oriented financial transactions for state fiscal appropriation in order to allocate capital more efficiently.

We put control variables into different conditioning information sets. The following control variables are chosen partly because they are conventionally used in the finance-growth literature, and partly because they are available in the data. We divide these control variables into four different conditioning information sets mainly to further test the sensitivity of the empirical results. The sets are defined as follows (and these variables are taken logarithms before entering into regression).

Small set. The logarithm of GDP in pervious year (Initial GDP) to capture the convergence effect, the logarithm of 'students enrollment of regular institutions of higher education per 10,000 persons' (Human capital) to control for the effect of human capital on growth.

Medium set. The small set plus the share of 'persons employed in private enterprises and self-employed individuals in urban areas' in 'persons employed in various units at year end' (Private) as a proxy for the progress of economic reforms, and the Consumer Price Index (CPI) to control for inflation. 
Large set. The medium set plus the ratio of foreign direct investment to GDP (FDI) to measure the degree of openness of the local economy, and government expenditure to GDP (Government) to control for the government size of each city and its role.

Full set. The large set plus the ratio of business volume of postal and telecommunication services to GDP (Postal \& Telecom) to indicate the role of information communication, and the density of roads (Infrastructure) as a proxy for local infrastructure condition. The density of roads is measured by the ratio of area of city paved roads to total land area of that city.

\subsection{Data}

Data in our sample are city-level. China has altogether 658 cities at three levels. Level 1: Four municipalities which are directly under the central government. They are Beijing, Shanghai, Tianjin and Chongqing. These 4 municipalities together with the other 22 provinces and 5 autonomous regions constitute the 31 provincial-level regions of mainland China. Level 2: 286 prefecture-level cities which are under the leadership of the provinces and autonomous regions. Level 3: 368 county-level cities which are under the leadership of the prefecture-level cities.

Our sample consists of 4 municipalities and 282 prefecture-level cities (we delete 4 prefecture-level cities from all the 286 because they lack complete data; one of them was just established in 2012).

Our dataset covers 286 Chinese cities over 2008-2013. All the data are from China City Statistical Yearbook and China Statistical Yearbook for various years.

\section{Finance and growth: cross-sectional analyses}

We first conduct a cross-sectional analysis focusing on the 'initial values' of financial indicators and control variables in the conditioning information sets of 2008 with the average value of the dependent variable over 2008-2013. That is, there is only one observation in each city. The basic cross-sectional model is as follows:

$$
\begin{aligned}
& \text { Growth }_{i}=\alpha+\beta \text { Finance }_{i}+ \\
& {[\text { Control Variables in the Set }]_{i}^{\prime} \gamma+\varepsilon_{i}}
\end{aligned}
$$

where $\mathrm{i}=1,2, \ldots, 286$ represent the 286 cities in our sample. The dependent variable is the average real GDP growth rate over 2008-1023, Finance takes values of each of the four financial indicators defined in Section 3.1, and control variables in different sets are also defined in Section 3.1.

The initial value regression can alleviate the critical weakness of the 'contemporaneous' regressions where dependent and independent variables are all averaged over the same period, notwithstanding, this analysis doe not address the issue of causality. There is a pitfall in the contemporaneous regressions, i.e., it is possible that a common shock to the dependent and independent variables occur in the same period (rather than the causation between them) that drives the empirical results. In other words, contemporaneous regressions may disregard the potential endogenous determinations of the dependent and independent variables.

Table 1 summarizes the OLS regression results with control variables in different sets. The results indicate a negative relationship between financial development and economic growth. We only report the coefficients on financial indicators to save space. Loans basically do not show any significant impact on growth, while the other three financial indicators all demonstrate significant negative effect on growth. In a word, our cross-sectional analyses do not show any positive role of financial development in economic growth.

Table 1. Finance and growth: OLS estimations (initial value regressions).

\begin{tabular}{|l|l|l|l|l|l|}
\hline $\begin{array}{l}\text { Conditioning } \\
\text { information set }\end{array}$ & & Loans & Deposits & Savings & Loan_to_Appro. \\
\hline Small set & Coefficient & 0.148 & -0.492 & -0.435 & $-0.334^{*}$ \\
\hline & Standard error & 0.3663 & 0.3604 & 0.4739 & 0.1790 \\
\hline & R-squared & 0.103 & 0.110 & 0.107 & 0.117 \\
\hline & Observation & 274 & 274 & 274 & 274 \\
\hline Medium set & Coefficient & 0.087 & -0.435 & -0.366 & -0.249 \\
\hline & Standard error & 0.3545 & 0.3416 & 0.4537 & 0.1521 \\
\hline & R-squared & 0.176 & 0.181 & 0.179 & 0.183 \\
\hline & Observation & 273 & 273 & 273 & 273 \\
\hline Large set & Coefficient & -0.194 & $-0.704 *$ & -0.685 & $-0.391 * *$ \\
\hline & Standard error & 0.2953 & 0.3832 & 0.4232 & 0.1681 \\
\hline & R-squared & 0.200 & 0.210 & 0.208 & 0.214 \\
\hline & Observation & 265 & 265 & 265 & 265 \\
\hline Full set & Coefficient & -0.085 & -0.575 & -0.520 & $-0.349^{* *}$ \\
\hline & Standard error & 0.3078 & 0.4366 & 0.4853 & 0.1661 \\
\hline
\end{tabular}




\begin{tabular}{|l|l|l|l|l|l|}
\hline & R-squared & 0.206 & 0.212 & 0.210 & 0.217 \\
\hline & Observation & 264 & 264 & 264 & 264 \\
\hline
\end{tabular}

$* * *, * *$ Significance levels at $1 \%$ and $5 \%$ respectively.

\section{Finance and growth: dynamic panel analyses}

\subsection{Model specification and methodology}

To examine the effect of financial development on GDP growth, we construct our basic regression model as follows:

$$
\begin{aligned}
& \text { Growth }_{i t}=\alpha+\beta \text { Finance }_{i t}+ \\
& {[\text { Conditioning Information Set }]_{i t}{ }^{\prime} \gamma} \\
& +\mu_{i}+\lambda_{t}+\varepsilon_{i t}
\end{aligned}
$$

where the subscript $\mathrm{i}$ stands for city $\mathrm{i}(\mathrm{i}=1, \ldots, 286)$ and $\mathrm{t}$ stands for year $\mathrm{t}(\mathrm{t}=2008, \ldots, 2013)$. $\mu_{i}$ are unobserved city-specific effects, $\lambda_{t}$ are time fixed effects, and $\varepsilon_{i t}$ is an idiosyncratic error term.

Table 2. Finance and growth: first-differenced GMM estimation.

\begin{tabular}{|l|l|l|l|l|l|}
\hline $\begin{array}{l}\text { Conditioning } \\
\text { information set }\end{array}$ & & Loans & Deposits & Savings & Loan_to_Appro. \\
\hline Small set & Coefficient & -4.950 & $-3.049^{*}$ & $-2.801^{*}$ & $-1.699^{* *}$ \\
\hline & Standard error & 3.0238 & 1.8078 & 1.6030 & 0.7442 \\
\hline & Sargan test (p-value) & 0.605 & 0.365 & 0.392 & 0.650 \\
\hline & Instruments & 14 & 14 & 14 & 14 \\
\hline & Observations & 1588 & 1588 & 1586 & 1615 \\
\hline Medium set & Coefficient & -3.331 & -2.312 & -2.617 & $-1.993^{* * *}$ \\
\hline & Standard error & 3.1666 & 2.0885 & 1.8856 & 0.7253 \\
\hline & Sargan test (p-value) & 0.225 & 0.153 & 0.172 & 0.454 \\
\hline & Instruments & 17 & 17 & 17 & 17 \\
\hline & Observations & 1566 & 1566 & 1565 & 1593 \\
\hline & Coefficient & $-8.702 * *$ & $-9.309 *$ & $-8.431^{* * *}$ & $-2.021^{* * *}$ \\
\hline & Standard error & 4.0807 & 4.7401 & 3.1242 & 0.4752 \\
\hline & Sargan test (p-value) & 0.522 & 0.345 & 0.518 & 0.826 \\
\hline & Instruments & 21 & 21 & 21 & 21 \\
\hline & Observations & 1494 & 1494 & 1494 & 1511 \\
\hline & Coefficient & -6.643 & -2.623 & 0.585 & $-2.020^{* * *}$ \\
\hline & Standard error & 4.4252 & 4.5618 & 4.2678 & 0.3660 \\
\hline & Sargan test (p-value) & 0.153 & 0.227 & 0.295 & 0.228 \\
\hline & Instruments & 25 & 25 & 25 & 25 \\
\hline & Observations & 1478 & 1478 & 1478 & 1495 \\
\hline
\end{tabular}

Notes: The test statistics and standard errors are asymptotically robust to heteroscedasticity.

$* * *, * *$, and $*$ stand for significant level at $1 \%, 5 \%$, and $10 \%$ respectively.

We use generalized method of moments (GMM) estimators to examine the effect of financial development on economic growth based on our sample dataset. There are several advantages of using GMM estimators for dynamic panel data (DPD) models. Firstly, we can control for both the city-specific effects and time effects. Secondly, we can choose appropriate lags of the independent variables as instruments to address the possible endogeneity in the regressions. As to the relation between financial development and economic growth, the joint determination between them may cause a simultaneous bias which would produce inconsistent estimators. Meanwhile, variables in the conditioning information sets may also suffer from the endogeneity problem. By using GMM estimators, we can solve these econometric problems with lagged observations of the independent variables as instruments. In this way we are capable of examining reliably the effect of exogenous components of financial development on economic growth. To save space, we omit the description of the econometric details of the GMM regressors.

Table 3. Finance and growth: system GMM estimations (full set)

\begin{tabular}{|l|l|l|l|l|}
\hline Regressors & model 1 & model 2 & model 3 & $\operatorname{model} 4$ \\
\hline
\end{tabular}




\begin{tabular}{|c|c|c|c|c|}
\hline & ( collapsed) & ( collapsed) & ( collapsed) & ( collapsed ) \\
\hline Loans & $\begin{array}{c}-2.146 \\
(1.8646)\end{array}$ & & & \\
\hline Deposits & & $\begin{array}{c}-2.126 \\
(3.7707)\end{array}$ & & \\
\hline Savings & & & $\begin{array}{c}-5.335 \\
(3.6973)\end{array}$ & \\
\hline Loans to Appro & & & & $\begin{array}{c}-2.057 * * * \\
(0.4028)\end{array}$ \\
\hline Initial GDP & $\begin{array}{c}-0.183 \\
(0.3142)\end{array}$ & $\begin{array}{c}-0.244 \\
(0.2897)\end{array}$ & $\begin{array}{c}-0.168 \\
(0.3125)\end{array}$ & $\begin{array}{c}-0.344 \\
(0.3220)\end{array}$ \\
\hline Human capital & $\begin{array}{c}0.333 \\
(1.0909)\end{array}$ & $\begin{array}{c}0.096 \\
(1.3941)\end{array}$ & $\begin{array}{c}-0.439 \\
(0.8653)\end{array}$ & $\begin{array}{c}-0.417 \\
(1.1815)\end{array}$ \\
\hline Private share & $\begin{array}{c}0.958 \\
(1.0989) \\
\end{array}$ & $\begin{array}{c}0.981 \\
(1.2927) \\
\end{array}$ & $\begin{array}{c}0.312 \\
(1.1591) \\
\end{array}$ & $\begin{array}{c}0.947 \\
(1.0985) \\
\end{array}$ \\
\hline CPI & $\begin{array}{c}0.140 \\
(0.3507)\end{array}$ & $\begin{array}{c}0.024 \\
(0.3969)\end{array}$ & $\begin{array}{c}0.020 \\
(0.3328)\end{array}$ & $\begin{array}{c}-1.132 \\
(0.3031)\end{array}$ \\
\hline FDI & $\begin{array}{c}0.577 \\
(0.8492)\end{array}$ & $\begin{array}{c}0.815 \\
(0.8171)\end{array}$ & $\begin{array}{c}0.585 \\
(0.7983)\end{array}$ & $\begin{array}{c}0.602 \\
(0.6857)\end{array}$ \\
\hline Government & $\begin{array}{c}-8.294^{*} \\
(4.4644)\end{array}$ & $\begin{array}{c}-10.538^{* *} \\
(4.3793)\end{array}$ & $\begin{array}{c}-6.333 \\
(5.7600)\end{array}$ & $\begin{array}{l}-8.681^{*} \\
(4.6916)\end{array}$ \\
\hline Postal \& Telecom & $\begin{array}{c}-0.021 \\
(1.0395)\end{array}$ & $\begin{array}{c}0.495 \\
(1.0255)\end{array}$ & $\begin{array}{c}0.629 \\
(1.1645)\end{array}$ & $\begin{array}{c}0.219 \\
(1.0610)\end{array}$ \\
\hline Infrastructure & $\begin{array}{c}-0.3432 \\
(2.0860)\end{array}$ & $\begin{array}{c}-1.544 \\
(2.2108)\end{array}$ & $\begin{array}{c}-0.523 \\
(1.6755)\end{array}$ & $\begin{array}{c}-0.762 \\
(2.1514)\end{array}$ \\
\hline Dummy yr2009 & $\begin{array}{c}3.005 \\
(2.4339)\end{array}$ & $\begin{array}{c}2.595 \\
(2.6965)\end{array}$ & $\begin{array}{c}2.026 \\
(2.2450)\end{array}$ & $\begin{array}{c}0.4158 \\
(1.9432)\end{array}$ \\
\hline Dummy yr2010 & $\begin{array}{l}6.162 * * * \\
(1.9070)\end{array}$ & $\begin{array}{c}6.326^{* * *} \\
(1.8547)\end{array}$ & $\begin{array}{l}5.450 * * * \\
(2.1014)\end{array}$ & $\begin{array}{c}4.386^{* * *} \\
(1.5854)\end{array}$ \\
\hline Dummy yr2011 & $\begin{array}{c}2.456^{*} \\
(1.2511)\end{array}$ & $\begin{array}{c}3.152 * * * \\
(1.1970)\end{array}$ & $\begin{array}{c}2.005 \\
(1.5926)\end{array}$ & $\begin{array}{c}1.908 \\
(1.3007)\end{array}$ \\
\hline Dummy yr2012 & $\begin{array}{c}2.622 \\
(1.8921)\end{array}$ & $\begin{array}{c}3.275^{*} \\
(1.8505)\end{array}$ & $\begin{array}{c}1.903 \\
(2.2233)\end{array}$ & $\begin{array}{c}0.869 \\
(1.7179)\end{array}$ \\
\hline Dummy yr2013 & $\begin{array}{c}2.393 \\
(2.3417)\end{array}$ & $\begin{array}{c}2.826 \\
(2.6401)\end{array}$ & $\begin{array}{c}1.677 \\
(2.6113)\end{array}$ & $\begin{array}{c}0.642 \\
(2.1280)\end{array}$ \\
\hline Dummy yr2014 & $\begin{array}{c}10.855 \\
(11.1488)\end{array}$ & $\begin{array}{c}11.826 \\
(12.9924)\end{array}$ & $\begin{array}{c}4.040 \\
(11.7567)\end{array}$ & $\begin{array}{c}8.2945 \\
(10.8745)\end{array}$ \\
\hline Lagged growth rate & $\begin{array}{c}0.481 * * * \\
(0.0719)\end{array}$ & $\begin{array}{c}0.517 * * * \\
(0.0813)\end{array}$ & $\begin{array}{c}0.475^{* * *} \\
(0.0791)\end{array}$ & $\begin{array}{c}0.436 * * * \\
(0.0657)\end{array}$ \\
\hline Constant & $\begin{array}{c}-27.095 \\
(48.6725)\end{array}$ & $\begin{array}{c}-9.342 \\
(56.5285)\end{array}$ & $\begin{array}{c}-2.108 \\
(42.9100)\end{array}$ & $\begin{array}{c}12.225 \\
(42.3333)\end{array}$ \\
\hline Observations & 1788 & 1788 & 1788 & 1807 \\
\hline Instruments & 26 & 26 & 26 & 26 \\
\hline Sargan test (p-value) & 0.990 & 0.920 & 0.997 & 0.988 \\
\hline $\begin{array}{l}\text { Arellano-Bond test for } \\
\text { AR(2) (p-value) }\end{array}$ & 0.742 & 0.904 & 0.868 & 0.605 \\
\hline
\end{tabular}

Notes: The standard errors are in parentheses. The test statistics and standard errors are asymptotically robust to heteroscedasticity. $* * *, * *$ and $*$ stand for significance levels at $1 \%, 5 \%$ and $10 \%$ respectively.

\subsection{Regression results}

Table 2 presents the regression results based on differenced GMM estimators. The results show that financial developmnet has no significant positive effects on economic growth: some financial indictors show a statistically negative impact on growth, for example, the variable Loan_to_Appro has negative effects on growth in all four models with four different sets of control variables, and all the four financial development indicators present significant negative effects on growth in the large set. The Sargan test of over-identifying restrictions, as well as the test for AR(2), is satisfactory. In a word, Table 2 does not offer any evidence of positive effect of financail development on growth.

Table 3 reports the system GMM estimates of Eq. (2) with the full set. We conduct two different regressions for each financial indictors by collapsing and un-collapsing the instruments in order to guarantee the credibility of system GMM estimators. Table 3 reports only the results from the collapsed regressions. Regression results in Table 3 are 
basically consistent with that of Table 2. Only Loan_to_Appro shows a significent negative effect on growth, and the other three financial indicators do not show any significant effects on economic growth. All the regressors pass the second serial correlation test and the Sargan test. All the p-values of the Sargan test comfortably satisfy the conventional significance levels with an average value of 0.9738 .

\section{Conclusion}

This paper examines the relationship between financial development and economic growth in China. We use data from 286 Chinese cities over the period 2008-2013. We employ first-difference and system GMM estimators for dynamic panel data. We do not find any significant positive effect of financial development on growth over this period. Most of the financial indicators do not have any significant effect on economic growth, while some of the indictors eve have significant negative effect on growth in the cross-sectional analyses. Our findings are consistent with many existing studies on China that suggest that financial development hinds economic growth due to the distorting nature of stateruled (even monopolized) banking sector, but run contrary to most cross-country studies on the relationship between financial development and economic growth. Thus, our findings suggest that the scarce capital had not flowed to the healthy and efficient firms who urgently need money, but was diverted to those inefficient large SOEs. The capital allocation mechanism of China's financial system has not been wholly market-oriented yet, which implies that there is still a long way to go for China's financial system reform.

Theoretically, we have a few remarks. Few would be inclined to deny that there is a rough parallel between economic and financial development. As real income and wealth increase, so do the size and complexity of the financial superstructure. Yet this is a loose relationship. It is hard to argue that a given volume or composition of financial assets is a sufficient condition for the development of real sectors of the economy - or even a necessary condition, given that rapid growth has sometimes taken place during periods of deliberate financial repression. We do admit, however, that financial innovation has at times sparked off virtuous circles of growth in particular sectors and regions, such as the successful microcredit movement in Bangladesh. As Greenwood and Jovanovic (1990) [38] said, if building a functional formal sector of financial intermediaries is arduous and costly, the evolution of financial structure and real economic development may well be mutually determined, with causation flowing in both directions.

\section{References}

1. J.A. Schumpeter, The Theory of Economic Development. Cambridge, MA: Harvard University Press (1911).

2. R.W. Goldsmith, Financial Structure and Development. New Heaven: Yale University Press (1969).

3. R.I. McKinnon, Money and Capital in Economic Development. Washington DC: Brookings Institutions (1973) .

4. J. Robinson J., The Rate of Interest and Other Essays. London: Macmillan (1952) .

5. R.E. Lucas Jr., Journal of Monetary Economics 22, pp. 3-42 (1988).

6. NBS (National Bureau of Statistics of China), China Statistical Yearbook 2016, Beijing: China Statistics Press (2016).

7. NBS (National Bureau of Statistisc of China), China China Compendium of Statistics 1949-2008, Beijing: China Statistics Press (2010).

8. G. Boyreau-Debray, The World Bank, Policy Research Working Paper Series 3027 (2003).

9. I. Hasan, P. Wachtel, M. Zhou, Journal of Banking \& Finance 33, pp. 157-170 (2009).

10. H. Chen, China Economic Review 17, pp. 347-362 (2006).

11. X. Cheng, H. Degryse, Bank of Finland Institute for Economies in Transition, BOFIT Discussion Papers 22/2007 (2007).

12. World Bank, Economic Growth in the 1990s: Learning from a Decade of Reform. Washington, DC: World Bank (2005).

13. R.G. King, R. Levine, Quarterly Journal of Economics 108, pp. 717-138 (1993).

14. M.H. Miller, Journal of Applied Corporate Finance 11, pp. 8-15 (1998).

15. R. Levine, S. Zervos, American Economic Review 88, pp. 537-558 (1998).

16. R. Levine, Journal of Financial Intermediation 8, 8-35 (1999) .

17. R. Levine, N. Loayza, T. Beck, Journal of Monetary Economics 46, pp. 31-77 (2000) .

18. F. Rioja, N. Valey, Economic Inquiry 42, pp. 127-140 (2004).

19. T. Beck, R. Levine, N. Loayza, Journal of Financial Economics 58, pp. 261-300 (2000).

20. P.L. Rousseau, P. Wachtel, Journal of International Money and Finance 21, pp. 777-793 (2002).

21. T. Beck, R. Levine, 2004, Journal of Banking \& Finance 28, pp. 423-442 (2004).

22. Z. Xu, Economic Inquiry 38, pp. 331-344 (2000). 
23. D.K. Christopoulos, E. G. Tsionas, Journal of Development Economics 73, pp. 55-74 (2004).

24. Bekaert B.G., C.R. Harvey and C. Lundblad, 2005, 'Does financial liberalization spur growth?' Journal of Financial Economics, Vol. 77, pp. 3-55.

25. J. Jayaratne, P. Strahan, Quarterly Journal of Economics 111, pp. 639-670 (1996) .

26. R. Dehejia, A. Lleras-Muney, National Bureau of Economic Research, Working Paper No. 9551 (2003).

27. P.L. Rousseau, Japan and the World Economy 11, pp. 185-198 (1999).

28. L. Guiso, P. Sapienza, L. Zingales, Quarterly Journal of Economics 119, pp. 929-969 (2004).

29. R. Rajan, L. Zingales, American Economic Review 88, pp. 559-586 (1998).

30. K. Kumar, R. Raghuram, L. Zingales, NBER Working Paper No. w.7208. Available at SSRN: http://ssrn.com/abstract=227556 (1999).

31. J. Wurgler, Journal of Financial Economics 58, pp. 187-214 (2000) .

32. N. Cetorelli, M. Gambera, Journal of Finance 56, pp. 617-648 (2001).

33. S. Claessens, L. Laeven, Journal of Finance 58, pp. 2401-2436 (2003).

34. T. Beck, A. Demirguc-Kunt, L. Laeven, R. Levine, Journal of Money, Credit and Banking 40, pp. 1379-1405 (2008).

35. A. Guariglia, S. Poncet, Journal of Comparative Economics 36, pp.633-657 (2008) .

36. T. Liu, K. Li, Journal of Asian Economics 12, pp. 245-262 (2001).

37. J. Zhang, S. Wang, Journal of Comparative Economics 40, pp. 393-412 (2012).

38. J. Greenwood, B. Jovanovic, J. Poli. Econ. 98, pp. 1076-1107 (1990). 